\title{
DETERMINAÇÃO DA MENOR CONCENTRAÇÃO DE BACTERIOCINA COM AÇÃO INIBITÓRIA SOBRE Staphylococcus aureus
}

\author{
SOUZA, N.B. ${ }^{1}$, CONTESSA, C. R. ${ }^{1}$, GONÇALO, G. B. ${ }^{1}$, ALMEIDA, L. ${ }^{1}$, MANERA, A. P. ${ }^{1}$, \\ MORAES, C. C. ${ }^{1}$ \\ ${ }^{1}$ Universidade Federal do Pampa (UNIPAMPA) - Bagé - RS - Brasil \\ E-mail para contato: nathieli.souza.1995@gmail.com
}

\begin{abstract}
RESUMO - Algumas classes de agente naturais podem ser empregadas na substituição de agentes químicos nos alimentos, dentre estes, tem-se as bacteriocinas. Estas são formadas por um grupo heterogêneo de peptídeos ou proteínas sintetizadas ribossomicamente que apresentam ação antimicrobiana contra uma vasta gama de micro-organismos patogênicos. Objetivou-se com este estudo a extração de uma bacteriocina produzida e excretada para o meio de cultivo, por Lactobacillus sakei, assim como a determinação da sua concentração mínima inibitória (CMI), frente ao micro-organismo Staphylococcus aureus. Após a obtenção do composto e a sua extração do meio de cultivo fermentado, diluiu-se em água peptonada estéril o extrato em um gradiente de concentrações de 1:2 até 1:12, assim todas as diluições e o extrato bruto foram testados pelo método de análise antimicrobiana em microplacas, contra o micro-organismo de interesse. A partir da análise dos resultados foi possível observar que o extrato apresenta uma ação bactericida no extrato bruto e na diluição de 1:2, a concentração mínima inibitória do composto foi encontrada na diluição de 1:9, na qual ainda apresente inibição do crescimento microbiano. Observa-se a produção de uma bacteriocina pelo Lactobacillus sakei assim como a extração deste composto do meio fermentado e sua ação antimicrobiana eficiente contra o micro-organismo Staphylococcus aureus.
\end{abstract}

\section{INTRODUÇÃO}

Vários agentes químicos ou sintéticos utilizados para inibição de micro-organismo em alimentos, estão sendo substituídos por agentes naturais. Estes com a mesma ação dos antimicrobianos químicos e sintéticos, todos com a finalidade de matar ou inibir o crescimento de micro-organismos indesejáveis no alimento (OLIVEIRA, et al., 2009).

A concentração mínima de um agente antimicrobiano pode ser determinada como sendo a menor quantidade deste composto que será necessária para inibir o crescimento de um micro-organismo escolhido, esta quantidade pode ser denominada como concentração mínima inibitória (CMI). São feitos testes com variação da concentração do agente antimicrobiano, quando esta concentração for a menor possível e ainda apresentar inibição do crescimento do contaminante, essa é definida como CMI (OLIVEIRA, et al., 2009). 
Dentro da classe de agentes naturais que podem ser utilizados na substituição de agentes químicos e sintéticos nos alimentos tem-se as bacteriocinas, esta classe de agente naturais é formada por um grupo heterogêneo de peptídeos ou proteínas sintetizadas ribossomicamente, que apresentam ação antimicrobiana contra uma vasta gama de micro-organismos patogênicos. Estas bacteriocinas podem ser utilizadas em alimentos, pois diferenciam dos antibióticos no seu espectro e modo de ação, à toxicidade e seus mecanismos de resistência, além da diferença na sua síntese (BISCOLA, 2011).

Conforme Eckner (1992) algumas bacteriocinas podem ser proteínas simples, porém outras produzidas por Staphylococcus, Clostridium e Lactobacillus podem conter grupamentos ativos de proteínas, lipídeos e carboidratos. As moléculas das bacteriocinas possuem regiões hidrofóbicas e hidrofílicas, responsáveis pelas interações com a superfície das células microbianas. Segundo Ecker (1992) e Desmazeaud (1997), a ação de bacteriocinas ocorre em duas fases, na primeira ocorre a absorção da bacteriocina pela membrana celular da célula sensível, nesta etapa a absorção é reversível e não há nenhum dano letal a célula. Em um segundo estágio a bacteriocina causa lesões letais a célula, com danos irreversíveis, no caso de micro-organismos Gram-positivos é possível observar anormalidades no transporte da membrana e/ou permeabilidade da membrana.

As bacteriocinas agem na formação de poros na membrana celular de células sensíveis, esta ação interfere em uma série de fatores importantes para a estabilidade das células, resultando no esvaziamento dos constituintes celulares e privam a célula de fontes essenciais de energia, com o colapso da célula, ocorre a paralisação de todas as reações, levando a morte celular (ARAUS, et al., 2009).

Com o aumento da frequência de doenças transmitidas por alimentos (DTA's) tanto por micro-organismos patogênicos como por intoxicações por compostos químicos e alergênicos, tem-se procurado por compostos naturais que tenham ação semelhante aos químicos e que sejam seguros ao consumo humano (NOGUEIRA e MIGUEL, 2009). Neste sentido, observase a eficiência na utilização de bacteriocinas e a necessidade de mais estudos na área de compostos naturais. Com base nestas informações objetivou-se a extração de uma bacteriocina produzida e excretada para o meio, por Lactobacillus sakei, assim como a determinação da concentração mínima inibitória do composto frente ao micro-organismo Staphylococcus aureus.

\section{METODOLOGIA}

\subsection{Produção de bacteriocina pelo micro-organismo}

A bacteriocina foi produzida por uma cepa de Lactobacillus sakei isolada de salame italiano, pelo grupo de estudos. Esta bactéria ácido lática foi mantida criopreservada $\left(-14^{\circ} \mathrm{C}\right)$ até ser utilizada, em meio de cultivo caldo MRS com $20 \%$ de glicerol, após realizou-se a reativação da bactéria em caldo MRS a $32^{\circ} \mathrm{C}$, com agitação de $150 \mathrm{rpm}$ por 12 horas.

\subsection{Separação do composto de interesse}

O caldo fermentado pela bactéria ácido láctica foi centrifugado a $5500 \mathrm{rpm}$ na temperatura de $4^{\circ} \mathrm{C}$ por 15 min., para a separação das células e a permanência do composto no 
meio sobrenadante restante da centrifugação, o precipitado rico em células foi então descartado. Este caldo fermentado sem a presença das células foi denominado de "Extrato livre de células".

\subsection{Diluição do extrato bruto}

Para análise mais detalhada da atividade do composto produzido pelo microorganismo foram feitas onze diluições sucessivas $(1: 2,1: 3,1: 4,1: 5,1: 6,1: 7,1: 8,1: 9,1$ :10, $1: 11,1: 12$ ) na qual a primeira diluição continha $1 \mathrm{~mL}$ de extrato bruto para $2 \mathrm{~mL}$ totais, mantendo-se sempre o volume inicial de extrato constante e aumentando o volume de diluente, neste caso água peptonada.

\subsection{Análise antimicrobiana dos extratos}

Foram feitas análise de microplacas baseadas na metodologia da NCCLS (2003) estas feitas com o extrato bruto (extrato livre de células sem diluição) e com as 11 diluições realizadas. Para as análises adicionou-se caldo Müeller Hinton, extrato a ser testado e microbiota Staphylococcus aureus ATCC® (12598). Foram feitas leituras de absorvância na faixa de $630 \eta \mathrm{m}$ em leitora de microplacas, estas foram feitas imediatamente após a inoculação do micro-organismo e $16 \pm 2 \mathrm{~h}$ após a incubação da microplaca em estufa bacteriológica a $35^{\circ} \mathrm{C}$, tempo de adaptação até a completa fase log do micro-organismo.

\section{REULTADOS E DISCUSSÕES}

Na Figura 1 são mostrados os resultados de inibição do extrato bruto assim como as do gradiente de concentrações do extrato diluído, frente ao micro-organismo $S$. aureus.

Figura 1: Ação inibitória do composto frente ao micro-organismo Staphylococcus aureus

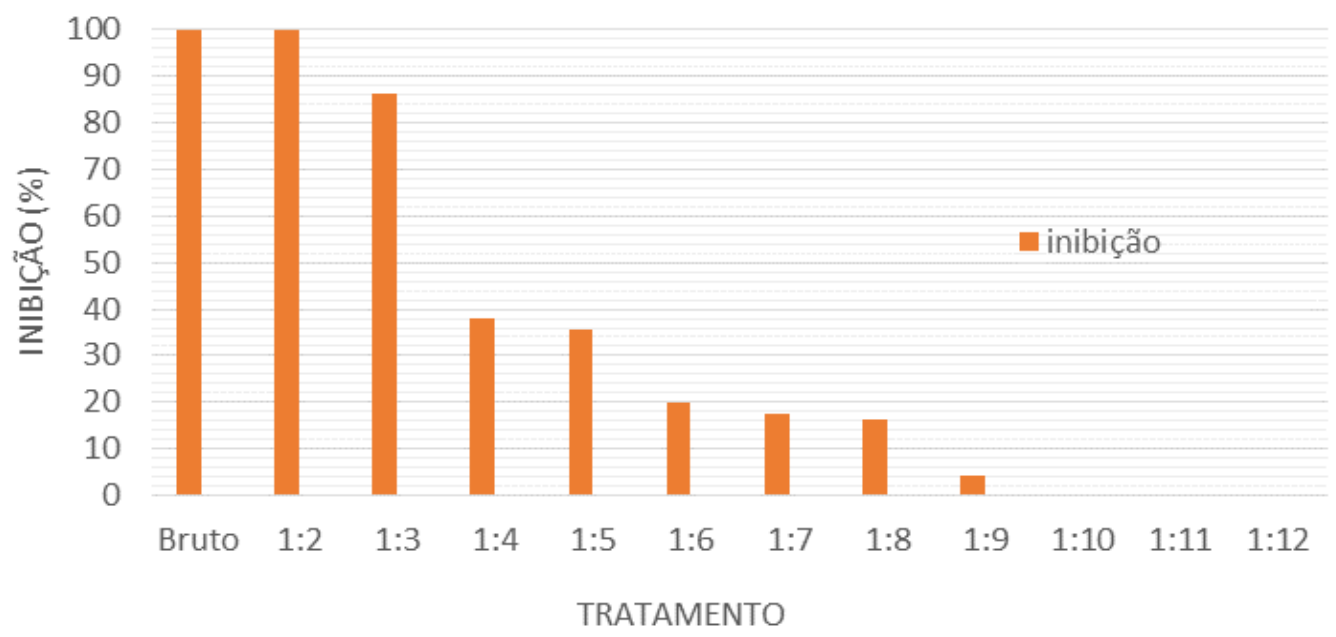

Através da figura é possível observar que a diminuição na porcentagem de inibição do micro-organismo está diretamente relacionada a diminuição da concentração do agente antimicrobiano no extrato utilizado. Observa-se que o agente antimicrobiano teve ação bacteriostática (o extrato inibe o crescimento, mas não destrói o patógeno) a partir da diluição 
1:3 até a 1:9 (1 mL de extrato para $9 \mathrm{~mL}$ totais), pois até a diluição de 1:3 o agente antimicrobiano tem ação bactericida sobre o contaminante. A partir desta concentração o composto encontrasse muito diluído no meio e não apresenta ação inibitória contra o microorganismo, ocorrendo o crescimento do mesmo na microplaca após as $16 \mathrm{~h}$.

Biscola (2011) em seus estudos descreveu alguns exemplos de bacteriocinas produzidas por bactérias láticas isoladas de produtos cárneos, no estudo foram isoladas 7 cepas diferentes de Lactobacillus sakei produtoras das bacteriocinas Lactocina S, Sakacina K, Sakacina P, Sakacina A, Bavaricina MN, no entanto, nenhuma delas apresentou ação contra o microorganismo Staphylococcus aureus, contudo, todas tiveram ação contra outro micro-organismo contaminante de alimentos, o que ilustra que a bacteriocina isolada no presente estudo tem ação diferente das descritas por Biscola (2011).

Rosa (2001) observou em seus estudos que uma bacteriocina produzida por cepa de Lactobacillus sakei, isolado de linguiça frescal, apresentou efeito antagônico contra Listeria monocytogenes, Listeria welshimeri, Listeria seeligeri e Listeria inocua, contudo não apresentou resultados satisfatórios contra cepas de Staphylococcus aureus e Escherichia coli O157:H7. Assim observa-se que a bacteriocina produzida pelo Lactobacillus sakei isolada no presente estudo tem ação diferente da bacteriocina produzida pela cepa isolada por Rosa (2001), observando-se assim a ampla gama de compostos produzidos por diferentes cepas deste micro-organismo.

Observa-se que o composto em baixas concentrações no extrato, apresenta potencial bacteriostático da diluição de 1:3 até a 1:9, sendo esta última a CMI. Também pode-se verificar que o extrato apresenta potencial bactericida quando utilizado na forma pura e na diluição 1:2, com isso observa-se a eficácia do agente, pois mesmo diluído no dobro do volume apresenta a mesma ação do composto inicialmente concentrado.

Lewus, et al. (1991) em seus estudos apresenta que bacteriocinas produzidas por bactérias láticas apresentam atividade bactericida contra uma série de micro-organismo patogênicos, tais como Bacillus cereus, Clostridium perfringens, L. monocytogenes e S. aureus, assim como os resultados encontrados neste estudo,

\section{CONSIDERAÇÕES FINAIS}

Observa-se a produção de uma bacteriocina pelo Lactobacillus sakei assim como a extração deste composto do meio fermentado e sua ação antimicrobiana eficiente contra o micro-organismo Staphylococcus aureus. Assim, através dos resultados encontrados, é possível concluir que o extrato além de ser eficiente no extrato bruto este permanece com ação bactericida na concentração 1:2 e tem como concentração mínima inibitória, nas condições estudadas, a diluição de 1:9, posteriormente a esta o gradiente de diluição não demonstra mais ação bacteriostática sobre o micro-organismo testado.

\section{AGRADECIMENTOS}

Ao CNPq, pelo apoio financeiro e incentivo a pesquisa e ao Laboratório de Microbiologia e Toxicologia de Alimentos pelo espaço físico. 


\section{REFERÊNCIAS}

ARAUZ, L. J., JOZALA, A. F., MAZZOLA, T. C. PENNA, V. Nisin biotechnological production and application: a review. Trends in food Science and Technology, v.20, p. 16154, 2009.

BISCOLA, V. Interações entre bactérias láticas produtoras de bacteriocinas e a microbiota autóctone de charque. Tese para obtenção do grau de Doutor em Ciências dos Alimentos. 75 p. 2011.

ECKNER, K. F. Bacteriocins and food applications. Dairy Food Environ. Sanit., Ames, v.12, n.4, p. 204-209, 1992.

DESMAUZEAUD, M. Bacteriocins of lactic acid bactéria (LAB) and their interest to improve the higienic quality of products. Tecnol. Lactea Latinoam. Buenos Aires, v.28, n.8, p. 38-43, 1997.

LEWUS, C. B., KAISER, A., MONTVILLE, T. J. Inhibition of food-borne bacterial pathogens by bacteriocins from lactic acid bacteria isolated from mead Appl. Environ. Microbiol., Washington, v.57, n.6, p. 1683-1688, 1991.

NCCLS: Metodologia dos testes de sensibilidade a agentes antimicrobianos por diluição para bactéria de crescimento aeróbico: Norma Aprovada - Ed.6,v. 23, nº. 2, 2003.

NOGUEIRA, J. M. R., MIGUEL, L. F. S. Bacteriologia. In. MOLINARO, E. M., CAPUTO, L. F. G., AMENDOEIRA, M. R. R. (orgs.) Conceitos e métodos para formação de profissionais em laboratório de saúde. Rio de janeiro: EPSJV; IOC, p. 221- 397, 2009.

OLIVEIRA, T. F., FERREIRA, J. S., SORTE, P. M. F. B., REIS, V. M., BADANI, J. I., SCHWAB, S. Concentração Mínima Inibitória (CMI) de antibiótico para oito estirpes de bactérias diazotróficas da Coleção de culturas da Embrapa Agrobiologia. Boletim de pesquisa e desenvolvimento - Embrapa. $1^{\text {a }}$ ed., 20 p, 2009.

ROSA, C. M. Purificação e mecanismo de ação de uma bacteriocina produzida por Lactobacillus sakei $2 a$ isolada de linguiça frescal. Tese para obtenção de grau de Doutor em Ciência dos Alimentos, p. 98, 2001 